NBER WORKING PAPER SERIES

\title{
MARKET INTEGRATION AND ECONOMIC DEVELOPMENT: A LONG-RUN COMPARISON
}

\author{
Wolfgang Keller \\ Carol H. Shiue \\ Working Paper 10300 \\ http://www.nber.org/papers/w10300 \\ NATIONAL BUREAU OF ECONOMIC RESEARCH \\ 1050 Massachusetts Avenue \\ Cambridge, MA 02138 \\ February 2004
}

We would like to thank Loren Brandt, John Giles, Timothy Guinnane, Kenneth Pomeranz, and T.N. Srinivasan, seminar participants at the University of Texas-Austin, Texas A\&M, and the 2000 Econometric Society Winter meetings for comments and suggestions. We have also benefited from communication with Zhang Peiyuan. Thanks go also to Alwyn Young for making the data used in Young (2000) available on his web page. The views expressed herein are those of the authors and not necessarily those of the National Bureau of Economic Research.

(C2004 by Wolfgang Keller and Carol H. Shiue. All rights reserved. Short sections of text, not to exceed two paragraphs, may be quoted without explicit permission provided that full credit, including (C notice, is given to the source. 
Market Integration and Economic Development: A Long-run Comparison

Wolfgang Keller and Carol H. Shiue

NBER Working Paper No. 10300

February 2004

JEL No. O1, O4, N7, F15

\section{$\underline{\text { ABSTRACT }}$}

How much of China's recent economic performance can be attributed to market-oriented reforms introduced in the last two decades? A long-run perspective may be important for understanding the process of economic development occurring today. This paper compares the integration of rice markets in China today and 270 years ago. In the 18th century, transport technology was nonmechanized, but markets were close to being free markets. We distinguish local harvest and weather from aggregate sources of price variation in a historical sample and in a similarly constructed contemporary sample. Findings indicate the degree of market integration in the 1720 s is a very good predictor of per capita income in the 1990s. Moreover, the current pattern of interregional income in China is strongly linked to persistent geographic factors that were already apparent several centuries ago, well before the enactment of modern reform programs.

Wolfgang Keller

Department of Economics

University of Texas at Austin

BRB 3. 152

Austin, TX 78712

and NBER

keller@eco.utexas.edu

Carol H. Shiue

Department of Economics

University of Texas at Austin

BRB 2. 126

Austin, TX 78712

shiue@eco.utexas.edu 


\section{Introduction}

Studies of economic growth in China generally begin their discussion with 1978, the year when contemporary reforms began, and circumscribe the analysis to the years since the mid-1980s, when data are more available. A longer-term perspective, however, may be important for understanding the process of economic development. In the case of Europe, there is now suggestive evidence that market integration and trade led to growth effects that took decades if not centuries to materialize (O'Rourke and Williamson 2004, Acemoglu, Johnson, and Robinson 2002). This paper fills the gap by taking a longer view on China. We examine market integration and trade in a sample of twelve Chinese provinces, home to about $17 \%$ of the world population, over almost three centuries (the years 1723 to 1993). ${ }^{4}$ Our point of departure is that assessments of China's reforms need to take into account differences across provinces that were already present before reforms began. Failure to do so would tend to lead to overestimates of the impact of reform.

This paper asks how market integration and trade for these economies have changed by distinguishing local from aggregate sources of price variation, an approach that has been widely adopted in economic history, development, as well as international economics (Clark 2002, Crucini 1999). Our findings indicate that in the late $20^{\text {th }}$ century, although the law of one price does not hold, local and national prices essentially move one to one. Compared to historical levels of market integration, contemporary markets are more integrated. But we also find a significant degree of market integration for distances up to about 700 kilometers in China in the early $18^{\text {th }}$ century. Moreover, the degree of market integration in the 1720 s is a very good predictor of per capita income in

\footnotetext{
${ }^{4}$ In 1993, these 12 provinces had a population of about 0.7 billion, which, given a world population of 5.4 billion, gives a share of $13 \%$. In the mid $18^{\text {th }}$ century, these provinces had a population of about 200 million, which according to the best estimates we have amounted to about $20 \%$ of the world population.
} 
the 1990s. This suggests that income differences across provinces today can to some extent traced back for at least three centuries.

This paper contributes to recent research in a number of areas. First of all, our analysis is related to the large literature on the impact of international trade on growth (Coe and Helpman 1995, Dinopoulos and Segerstrom 2003, Frankel and Romer 1999, Keller 1998, Xu and Wang 2001). Our analysis differs in that instead of international trade we focus on trade within China's borders. ${ }^{5}$ We also provide some important historical background to research of economic reform and regional growth in China (see Young 2000 for a good introduction). In addition, this paper contributes to what is known on pre-industrial China, important because it may give clues on why China grew so much slower than Western Europe and North America from about 1750 to 1950 (Pomeranz 2000, Shiue 2002, Shiue and Keller 2003). What is different here is that our analysis spans from the pre-industrialization to the modern era. Finally, if markets themselves are viewed as economic institutions — a view that we are inclined to take-our analysis mirrors the new emphasis on the importance of institutions for growth (Acemoglu, Johnson, and Robinson 2001, Banerjee and Iyer 2002).

The paper is organized as follows. Section 2 introduces our empirical approach. We highlight major characteristics of the data in the following section. All empirical results are contained in section 4 , while section 5 provides a concluding discussion.

\footnotetext{
${ }^{5}$ Such trade can be quite important. In fact, Irwin argues that for the period of 1500-2000, intra-continental trade--such as trade within Europe or similar-sized China--was quantitatively more important than intercontinental trade, which economists have studied more intensively so far (Irwin 2003, 63).
} 


\section{Approach}

We want to distinguish local from global shocks that influence local prices.

Conditional on demand, if markets are fully integrated only global supply shocks determine how prices move in all regions. This is because even if there are regionspecific supply shocks, the regions can achieve full risk sharing through trade (highoutput regions export, low-output regions import). By contrast, the existence of trade barriers will give rise to a partial segmentation of markets. In this case local supply shocks will play a role in determining local price movements. Thus, in a regression framework, the local price $P_{i t}$ may be determined by both local (L) and national (N) factors

$$
P_{i t}=\alpha+\beta_{L} L_{i t}+\beta_{N} N_{t}+\varepsilon_{i t}
$$

where $i$ indexes province, $i=1, \ldots, I$, and $t$ indicates time $t=1, \ldots, T$.

We do not have data on the provinces' supplies for our entire sample period.

Instead, we use the aggregate price as our measure of global supply, defined as

$$
\bar{P}_{i t}=\sum_{i \neq j, j=1}^{I} s_{i j} P_{j t}, \forall i, t,
$$

where $s_{i j}$ denotes the size of province $\mathrm{j}$ in the computation of the aggregate price for

$$
\text { province i }\left(\sum_{i \neq j, j=1}^{I} s_{i j}=1, \forall i\right){ }^{7}
$$

We have two types of measures of the local conditions: the first is local weather

\footnotetext{
${ }^{6}$ Our analysis abstracts from international trade, because it was largely prohibited and hardly existed in the case of China in the early $18^{\text {th }}$ century. In the late $20^{\text {th }}$ century, China's international trade plays a greater role; see, e.g., Dinopoulos and Segerstrom (2003) who study the effects of China's accession to the World Trade Organization.

${ }^{7}$ We exclude the price in province $i$ in the computation of the aggregate price in order to avoid a built-in correlation between the dependent and an independent variable in equation (1). This definition of $\bar{P}_{i t}$ implies that the "national" conditions vary by province.
} 
$($ denoted $w)$. Weather, and more generally, climatic conditions, have an important effect on agricultural production. The second local variable is a measure of the harvest quality relative to what is normal in that province (denoted by $h$ ); this captures a number of unobserved factors that influence rice output in addition to weather, including technology shocks. All else equal, favorable local weather and a high local harvest quality will lower the local relative to the national price as long as there is no perfect arbitrage across provinces.

The definition of the aggregate price in equation (2) implicitly assumes that conditional on size differences, all provinces are equally important in determining the aggregate price. This may be plausible if indeed trade barriers are close to zero, but not if they are still significant. Even in the United States today, for example, prices in New York matter often more for Connecticut prices than those prevailing in California, and based on direct evidence from historical sources on grain trade in early $18^{\text {th }}$ century China, we know that trade barriers limited trading possibilities over long distances. The bilateral unit trade costs between provinces $\mathrm{i}$ and $\mathrm{j}$ can be expected to rise with geographic distance between $\mathrm{i}$ and $\mathrm{j}\left(\right.$ denoted $\left.\mathrm{d}_{\mathrm{ij}}\right){ }^{8}$ Thus, the national market condition from the point of view of province i might be determined by only a subset of other provinces, especially those for which the price difference $\left(P_{i}-P_{j}\right)$ is less than the unit transports from $\mathrm{i}$ to $\mathrm{j}$. If we denote this as the effective aggregate price, it may for province $\mathrm{i}$ be written as

\footnotetext{
${ }^{8}$ In $18^{\text {th }}$ century China, the size of the per diem ration of rice determined the distance over which grain trade through porters was feasible. In today's economies, distance often determines shipping times and hence transport costs; see e.g. Hummels (1999). In addition, there are distance-invariant trade costs, such as those related to loading and unloading.
} 


$$
\bar{P}_{i t}^{e}=\sum_{i \neq j, j=1}^{I} s_{i j} \psi\left(d_{i j}\right) P_{j t}, \forall i, t,
$$

where the function $\psi\left(d_{i j}\right)$ captures this dependence on distance. A particularly simple version of this function that we will employ below is an indicator function, returning the value 1 if $\mathrm{d}_{\mathrm{ij}}$ is less than some threshold level, and 0 otherwise.

To summarize, we will employ regressions of the following form:

$$
p_{i t}=\beta_{0}+\beta z_{i t}+\beta_{1} \bar{p}_{i t}^{e}+\beta_{2} w_{i t}+\beta_{3} h_{i t}+\varepsilon_{i t},
$$

where the z's are control variables, $p_{i t}=\ln P_{i t}$, analogously, $\bar{p}_{i t}{ }^{e}=\ln \bar{P}_{i t}{ }^{e}$, and $\varepsilon_{i t}$ is assumed to be a mean-zero error term.

\section{Data}

The sample consists of twelve Chinese provinces. These are Anhwei, Fujian, Guangdong, Guangxi, Guizhou, Hubei, Hunan, Jiangsu, Jiangxi, Sichuan, Yunnan, and Zhejiang; they are contiguous and are located in the central and southern part of China, see Figure $1{ }^{9}$ The maximum distance between the capitals of any two provinces is almost 1,800 kilometers $(\mathrm{km})$. We focus on rice, the most important agricultural crop in China. Therefore this study does not cover the Northern provinces and the metropolitan area around the capital of Beijing (Zhili province), because the climate of the North was not suited to rice farming as the South's was, and rice prices were thus less frequently recorded.

\footnotetext{
${ }^{9}$ Figure 1 shows a late $20^{\text {th }}$ century map of China. The provincial boundaries in the early $18^{\text {th }}$ were similar to the $20^{\text {th }}$ century boundaries, with small exceptions such as Shanghai, which was a part of Jiangsu and is now independent. Our analysis takes this into account.
} 
Our sample period consists of two sets of years, one in the $18^{\text {th }}$ and one in the $20^{\text {th }}$ century. The $18^{\text {th }}$ century period covers the years 1723 to 1735 . The price data we employ is on the prevailing market price in the provincial capital. The original source of these data is the Yongcheng zhupi yuzhi (Vermillion endorsements and palace memorials of the Yongzheng period). Yongzheng (1723-35) succeeded to the throne upon the death of his father Kangxi (reign 1662-1722), and was the third of ten emperors who ruled during the Qing dynasty (1644-1911). Important procedures, originating with Kangxi, of what was to become a routine reporting system that transmitted data on prices, harvests, and weather reports from locations throughout the empire to the capital in Beijing were developed and expanded upon during Yongzheng's rule.

The creation of the price reports began at the county level, where details on crops, harvest predictions, weather, and prevailing prices from the local county market were compiled every ten to 30 days. County officials sent their reports to the next higher authorities, the prefectural level, where the price reports were summarized and sent to the provincial governors. A detailed summary of all these reports was used by the provincial governor to prepare his report (memorial) to the emperor on the conditions in the province.

The Qing emperors' interest in price and harvest conditions across the empire can in part be explained with general concerns about the legitimacy of governance from a political and economic point of view, since a severe weather shock could result in food crises and instability. Thus, the grain price report system served as an early warning system for potential problem areas. More importantly, the system of audits and checks on the regular reports, the standardization of the form and content in the reports, and the 
very practical functions of price information for official purchases of grain, also suggest that the information contained in the reports are useful and valid. ${ }^{10}$ Chuan and Kraus (1975) report prices at a monthly frequency, albeit not for all provinces and all years. We have aggregated the data to an annual level, which is the same frequency as the data we have for these provinces in the late $20^{\text {th }}$ century (see below).

Table 1 provides an overview of the data. The average of all prices is about 1.2 the period 1723-35 (on the left), with the by-province mean varying from about 1 in Guizhou to about 1.5 in Zhejiang. ${ }^{11}$ Prices are reported in units of taels (silver ounces) per shi of rice, where one shi equals about 103.8 liters. The local prices are used to compute aggregate prices. We obtain the relative size of the provinces in this sample using fiscal land acreage (Wang 1973), shown in Table 1, at the bottom. ${ }^{12}$ Summary statistics on the aggregate price variable are shown in column two of Table 1.

Historical records on harvest for a large geographical area are often scarce or nonexistent. ${ }^{13}$ In the case of China, however, some records on harvest quality exist and are available to us. ${ }^{14}$ Often the only information available is an overall assessment of harvest quality for the province as a whole, and there is one value for each harvest cycle. ${ }^{15}$ Harvests are not reported in terms of absolute levels of output, but as a percentage of

\footnotetext{
${ }^{10}$ Chinese records on grain prices date to as early as the Tang Dynasty (618-906). For more details on the origin, functions, purposes, and reliability of the grain price reporting system in the Qing Dynasty, see Wilkinson (1969), Wang (1987), Wang (1989), Chuan and Kraus (1975).

${ }^{11}$ The number of observations varies across provinces, with a total of 112 observations.

${ }^{12}$ These 12 values $s_{i}$ give rise to $132 s_{i j}$ when we drop the own weight $\left(s_{i i}=0\right.$, for all $\left.i\right)$, and rescale so that the sum over all $\mathrm{j}$ is equal to 1 , for all $\mathrm{i}$.

${ }^{13}$ For most European nations, for example, price fluctuations are the only evidence for harvest quality that we have; Persson, (1999). An exception is Clark (2002), who uses harvest records from medieval England.

${ }^{14}$ See Chuan and Kraus (1975), and also Gong and Zhang (1983).

${ }^{15}$ Typically, there is one harvest cycle per year. In five of the twelve provinces, however, it was possible to harvest twice per year (Fujian, Guangdong, Guangxi, Jiangxi, and Zhejiang). If information on both harvests is available, our annual harvest measure is the average of the two for these provinces. All dates have been converted from the original lunar system of dating to the solar calendar. See Chuan and Kraus (1975) for details on the timing of harvests, especially p. 99, and pp. 119-166.
} 
maximal output (100 percent) that could be expected in that province. It is plausible to view these percentages as an indicator of harvest quality. Harvest quality ranges from $50 \%$ ('poor harvest') to $100 \%$ ('excellent harvest') in the data, and are typically reported by ten-percentage point gradations. ${ }^{16}$ Table 1 shows summary statistics on harvest quality in column 3.

Our source for historical weather data are the weather maps in the State Meteorological Administration (1981). This gives weather data throughout China for each year for 120 "stations", where about five such stations are located in each province. We use the data for the station in the provincial capital. This is a discrete indicator of the degree of "wetness and aridity", from floods, droughts, monsoons, or rainfall, relative to what is considered normal for that region (denoted by $\mathrm{R}_{\mathrm{it}}$ ). Bad weather ranks are 1 and 5 (severe drought and flood), fair weather ranks are 2 and 4 (limited drought and floods), and good weather is rank 3 (favorable conditions). Our weather variable is defined as $w_{i t}=\left|R_{i t}-3\right|$, so that higher values of $\mathrm{w}_{\mathrm{it}}$ indicate worse weather $\left(\mathrm{w}_{\mathrm{it}}\right.$ takes on the values 0,1 , and 2). Summary statistics on this variable are shown in Table 1, column 4.

We can be comparatively brief in describing the data for our $20^{\text {th }}$ century period, as this data is better known and also has been carefully analyzed recently in a paper by Alwyn Young (Young 2000). ${ }^{17}$ Our sample period is 1986-93, for which we have annual data on the price of rice purchased by commercial establishments in the 12 provinces. ${ }^{18}$

\footnotetext{
${ }^{16}$ A $70 \%$ harvest is typically recorded as 'fair', while $80 \%$ and $90 \%$ harvest are 'fair/good' and 'good', respectively.

${ }^{17}$ We thank A. Young for posting this data at his website; all the data described in the following comes from this source. The original sources of Young's data are public, including Province Statistical Yearbooks, China Statistical Yearbooks, and China Price Statistics Yearbooks. For more details on the nature and original sources of the data, we direct the reader to Young's (2000) paper.

${ }^{18}$ We prefer this series to the also available (and sometimes longer) retail price series, because in the case of rice the retail prices appear to be influenced more strongly by subsidies that vary across provinces and over time. The exact product description is long-grained nonglutinous rice (Indica rice).
} 
Summary statistics on this variable are given in Table 1, column 5; the prices are quoted in yuan per 100 kilogram. As our measure of province size, we use the total grain sown areas in each province, averaged in the years 1980 and 1985. From that we compute shares for the 12 provinces in our sample, shown in Table 1, at the bottom. Summary statistics of the aggregate prices based on that are presented in column 6 .

We have constructed our measure of harvest quality as the residual from a regression of output on labor and capital in agriculture. This is not only a measure of harvest quality, but as long as other shocks (demand, productivity) are not perfectly correlated with weather shocks, the residual should be correlated with differences in harvest quality. ${ }^{19}$ Summary statistics for this are shown in column 7 of Table 1 . The weather data is monthly average rainfall in a year, measured in centimeters, and the weather variability measure is the coefficient of variation of rainfall across months in a given province. Summary statistics on these variables are shown in Table 1, columns 8 and 9 , respectively.

To incorporate the geographic dimension in this sample of Chinese provinces, we use the bilateral distances between provinces (measured as the distance between provincial capitals). These figures are reported in Table 2. Finally, the GDP and population figures we employ below to compute income per capita are taken from provincial statistical yearbooks (source: Young 2000).

The next section discusses the empirical results.

\footnotetext{
${ }^{19}$ The regression of log agricultural output on log labor (employment in primary sector), log capital (power of agricultural machinery, in kilowatt), and provincial fixed effects results in an $\mathrm{R}^{2}$ of about 0.98 ; we include the fixed effects to obtain a harvest measure relative to what is normal in the province, the measure we have for the $18^{\text {th }}$ century period.
} 


\section{Empirical results}

\subsection{Market integration in the late $20^{\text {th }}$ century and early $18^{\text {th }}$ century}

The results for the period 1986 to 1993 are presented in Table 3. These are variants of equation (4) in which the function $\psi\left(d_{i j}\right)$ is set to one for now. In specification (1), the aggregate price effect enters with a coefficient of 0.966 and accounts for about three quarters of the variation in local prices $\left(\bar{R}^{2}\right.$ of 0.756$)$. This suggests that aggregate rice price movements are quite important. ${ }^{20}$

The weather variable does not enter significantly (see (2)). It may be that this relationship is non-linear; including additional higher order terms in the regression though does not change the finding. However, according to (3) if both rainfall and its variability are considered simultaneously, this is associated with higher prices, all else equal. In contrast, the quality of the local harvest has no impact on the local price (specification (4)). Including any of these additional variables has almost no impact on the coefficient of the aggregate price, which remains around 0.97 .

In the remaining three specifications, we include fixed effects for the 12 provinces. This serves as a control for time-invariant province-specific unobserved heterogeneity that might affect price, such as differences in taste. It comes at the cost of giving up any between-province price variation. The main consequence is that there is no significant relation between weather variability and local price anymore. The harvest variable enters with the expected sign (negative) but remains insignificant.

\footnotetext{
${ }^{20}$ A common trend might explain part of this finding. We do not have long enough time series to study this formally, but we have experimented with including a trend. It is typically not significant and does not change our qualitative findings. For example, in (1) the coefficient on the trend is 0.010 (s.e. 0.011), while the coefficient for the aggregate price term is 0.877 (s.e. 0.106). For a more extensive treatment of common trends and cointegration in price series, see Shiue and Keller (2003).
} 
What about economic magnitudes? In specification (3), a $10 \%$ increase in local rainfall and rainfall variability is associated with about a $0.8 \%$ and $0.9 \%$, respectively, higher local price, and most of this effect appears to be province-specific (the weather variable turns insignificant when province fixed effects are included). The coefficient of 0.972 on aggregate price means that a $10 \%$ increase in the aggregate price of rice (excluding province i) is associated with a price increase of $9.72 \%$ in province $i$, on average. Given the standard error, one cannot reject the null hypothesis that, on average, local and aggregate prices move one for one. For the modern sample period then, the source of local price movements seems to be mainly aggregate shocks.

Overall, this is evidence for a well-integrated grain market. At the same time, this does not mean that there is perfect integration, or that there could not be a reversal of integration. In specification (7), we allow the aggregate price effect to vary between 1986-89 and 1990-93. Although the estimates do not differ significantly, a somewhat higher effect is estimated for the earlier compared to the later period. The result confirms Young's (2000) finding that there has not been an unambiguously positive trend towards better market integration in China over the late 1980s and 1990s. As more data becomes available, it will be possible to see whether the early 1990s were a temporary blip or a major turning point. Here, we want to go into the other direction, time-wise, and examine rice markets in the same provinces about 270 years earlier.

The results for the years 1723 to 1735 are shown in Table 4. In specification (1), the aggregate price coefficient is positive, as before. However, first, the point estimate now is 0.530 , as opposed to 0.966 in the $1980 / 90 \mathrm{~s}$. Even though the estimate of 0.530 is not very 
precise, one can reject the null hypothesis that it is equal to one at standard levels (the $95 \%$ confidence interval is $[0.192,0.868])$. Second, the aggregate price accounts for only about six percent of the variation in local prices, whereas before, it accounted for seventy-five percent. In addition to greater measurement error in the earlier period, which almost surely plays a role, this suggests that aggregate market conditions do not matter nearly as much in the early $18^{\text {th }}$ century as they do in the late $20^{\text {th }}$ century.

Consistent with this idea, we find the local weather variable entering significantly in specification (2). The estimate suggests that price in a moderate draught or flood are on average $5.8 \%$ higher than under normal weather conditions, with an additional $5.8 \%$ price increase when a severe flood or draught occurs. Next, we consider the harvest quality variable. ${ }^{21}$ The results suggest that the quality of the local harvest has a strong effect on local prices: for a harvest improvement from the first to the third sample quartile, the local price is predicted to fall by about $8 \% .^{22}$ In addition, the aggregate price is not significantly correlated anymore with local prices.

The following two specifications introduce fixed effects for the provinces. Given the lower $\bar{R}^{2}$ of these regressions relative to those for the $20^{\text {th }}$ century, there may be important unobserved heterogeneity that these fixed effects can control for. The coefficient on aggregate price in (4) is estimated to be not very different from the value of in the comparable specification (2), without fixed effects (0.474 vs. 0.488$)$. At the same time, the $\bar{R}^{2}$ change indicates that unobserved heterogeneity across provinces plays a major role. When the local harvest variable is added, it is significant while aggregate market conditions are not anymore (see (5)).

\footnotetext{
${ }^{21}$ This reduces the size of our sample, see Table 4.

${ }^{22}$ The first quartile is $78 \%$ of the harvest, the third quartile is $90 \%$, and $(0.90-0.78) \times-0.686=-0.082$.
} 
Overall, these findings suggest that in the late $20^{\text {th }}$ century, aggregate effects are far more important than local factors, whereas in the early $18^{\text {th }}$ century the reverse is true: local factors dominate, and aggregate conditions do not affect local prices significantly. This indicates that a national market did not yet exist in the $18^{\text {th }}$ century, ${ }^{23}$ but something closer to being considered a nationally integrated market exists today. For the 1720 s, this raises the question of what was the scope of China's rice markets at the sub-national level—over what distances do we find evidence for market integration and trade?

To bring this sharper into focus, we introduce geographic features in the next section.

\subsection{The scope of markets in geographic space}

Table 2 shows that bilateral distances between provincial capitals in our sample lie between 234 and $1797 \mathrm{~km}$, with a median value of $760 \mathrm{~km}$. In the following, we construct aggregate price measures separately for relatively near and relatively far provinces, based on some threshold distance, $\bar{d}$. To this effect, we define the indicator function $I\left(d_{i j}, \bar{d}\right)$ which equals one if $d_{i j}<\bar{d}$, and zero otherwise. Analogously, we define another indicator function, $\widetilde{I}\left(d_{i j}, \bar{d}\right)$, which equals one if $d_{i j} \geq \bar{d}$, and zero otherwise; the corresponding aggregate prices are $\bar{p}_{i t}^{e, n}$ (superscript "n" for near) and $\bar{p}_{i t}^{e, f}$ (superscript "f" for far). ${ }^{24}$

We then consider the following regression:

\footnotetext{
${ }^{23}$ The fact that long-distance, inter-provincial trade took place in the $18^{\text {th }}$ and $19^{\text {th }}$ centuries (see Perkins 1969, Wang 1989) is not inconsistent with there being a lack of national markets according to the measure of integration used here.

${ }^{24}$ The "near" aggregate price is defined as $\quad \bar{p}_{i t}^{e, n}=\ln \left[\sum_{i \neq j, j=1}^{I} s_{i j} I\left(d_{i j}, \bar{d}\right) P_{j t}\right], \forall i, t$, and the $\bar{p}_{i t}^{e, f}$ variable is analogously defined and based on $\tilde{I}\left(d_{i j}, \bar{d}\right)$
} 


$$
p_{i t}=\beta_{0}+\beta_{n} \bar{p}_{i t}^{e, n}+\beta_{f} \bar{p}_{i t}^{e, f}+\varepsilon_{i t},
$$

where $\beta_{n}$ estimates the impact of aggregate market conditions in near-by provinces, while $\beta_{f}$ is for aggregate market conditions in provinces that are above the threshold distance $\bar{d}$ away. A simple grid search over threshold distances gives $700 \mathrm{~km}$ as the value that maximizes the fit of equation (5) for the 1723-35 period; we take $\bar{d}=700$ as our threshold value. Conditional on this distance threshold, Table 5 shows estimation results for both the $1723 / 35$ and $1986 / 93$ samples.

In the early sample period, $\beta_{n}$ and $\beta_{f}$ are estimated to be 0.578 and about zero, respectively, whereas in the later period the corresponding values are 0.618 and 0.344 (columns 1a and 1b). The changes in the degree of market integration over these 270 years can be gauged in a number of ways. First, if price in all other provinces go up by $10 \%$, the predicted local price increase in the earlier period is $5-6 \%$, while it is close to the full $10 \%$ in the later period; these results confirm the earlier regressions. This move from a correlation of local with aggregate prices from about 0.5 to close to 1 points to a substantial increase in the degree of market integration.

Second, for the early $18^{\text {th }}$ century prices in provinces that are more than $700 \mathrm{~km}$ away do not influence the effective aggregate price at all, or, to put this differently, $100 \%$ of the aggregate price effect comes from provinces that lie within $700 \mathrm{~km}$ of distance. By contrast, for the late $20^{\text {th }}$ century sample provinces beyond the $700 \mathrm{~km}$ distance range contribute about $1 / 3$ of the total effect $(0.344 /(0.344+0.618))$. Changes in market integration seem to be in part the result of establishing market linkages over longer distances. Third, the distinction of near versus far provinces is much more important in the $18^{\text {th }}$ than in the $20^{\text {th }}$ century. This is another indication of the fact that geographic 
distance matters much less in the later period: comparing the regression fit in Tables 3, 4, and 5, we see that the $\bar{R}^{2}$ more than doubles upon the separation of near versus far provinces in the early period, whereas the $\bar{R}^{2}$ for the later period actually falls slightly.

The additional regression results presented in Table 5 largely confirm these results. An exception is specification (4a): when near and far aggregate prices are distinguished, we estimate a positive and significant aggregate price effect in the earlier period even conditional on harvest quality. Without the near/far distinction, there was no significant aggregate price effect (see Table 3, specification (5)). The results suggest that local and aggregate shocks (with distance of less than $700 \mathrm{~km}$ ) have effects of roughly the same order of magnitude: a 10\% increase in this aggregate price is associated with a $5-6 \%$ local price increase, while a $10 \%$ better harvest is associated with a $6 \%$ lower local price, on average. ${ }^{25}$

This modifies our earlier conclusion for the $18^{\text {th }}$ century period that all variation in local prices has local sources. We continue to find that price shocks in provinces that are relatively far away do not matter, but price movements in markets at intermediate distances (up to 700km) account for about half of the variation in local prices, with local harvest shocks accounting for the other half. For the late $20^{\text {th }}$ century, the findings are on the whole unchanged, with aggregate effects playing the dominant role.

In the following section, we examine the relationship between our measures of market integration and income.

\footnotetext{
${ }^{25}$ The introduction of provincial fixed effects also reverses the relative importance of near versus far sources of aggregate price effects (see (column 4b)). Primarily, this seems to be an artifact of prices being positively spatially correlated; the introduction of province fixed effects tends to eliminate variation that would otherwise suggest co-movements of prices within a relatively close distance $(<700 \mathrm{~km})$. We thus think it is less important. See Keller and Shiue (2003) for more on spatial correlation in this context.
} 


\subsection{Market integration, trade, and income}

We now turn to the question of whether differences in market access and trade are related to income differences across provinces. The evidence presented above suggests that market integration and trade have increased substantially between the early $18^{\text {th }}$ and late $20^{\text {th }}$ century. At the same time, we know that per capita income in these provinces has risen as well, even if we do not have exact figures for the $18^{\text {th }}$ century period. Thus, we observe more trade at the same time when we observe higher incomes. But can we say more than that?

To this end, we examine whether there are differences across provinces in terms of market access and trade at a given point in time. In our framework, this amounts to asking whether the aggregate price is more important in explaining local price variation in some versus in other provinces. While there is not enough data for a regression analysis (roughly 8 observations per province in 1986/93), we can aggregate the provinces into groups and then examine how market integration varies with income across groups.

For each of the 12 provinces, we compute their median GDP per capita from the years 1986 to 1993 . These values range from a high of 2,640 yuan in Jiangsu (including Shanghai) to 770 yuan in Guizhou. We classify the 12 provinces into 3 groups with 4 provinces each, called Low-, Mid-, and High GDP per capita group, and compute for these 3 groups our measure of market integration (median of correlation of local with aggregate price) ${ }^{26}$

Figure 2, on the left, shows the results. There is no major difference in terms of market integration and trade between the 'Mid' and 'High' provinces, while there is some

\footnotetext{
${ }^{26}$ This is the aggregate price for distances of less than $700 \mathrm{~km}$ in both sample periods.
} 
between the relatively poor and the other provinces ( 0.91 for 'Low', and 0.96 for 'High' incomes). This is consistent with relatively good market integration and trade being a cause of relatively high income. At the same time, the differences across the regions are, with about five percentage points, not large, at least relative to the uncertainty associated with these estimates.

How about the earlier period? As noted above, we do not have good measures of provincial incomes at that time. But we can compare our measures of market integration and trade of the period 1723-35 with the GDP per capita figures for 1986-93. This is shown in Figure 2 on the right. The 'Low' income provinces of the late $20^{\text {th }}$ century had market integration values around 0.35 , whereas the 'High' income provinces had values around 0.68 , with the 'Mid' group in between. The analysis above already indicated that all early $18^{\text {th }}$ century levels of market integration would lie considerably below the $20^{\text {th }}$ century values. Thus, what is new here is that market integration and trade in $1720 \mathrm{~s} / 30 \mathrm{~s}$ is a good predictor of GDP per capita in the late $20^{\text {th }}$ century.

One implication of this finding is that relying on only a relatively short time horizon to assess the impact of market reform in China is misleading. Since the inception of the reforms of the 1980s, it may well be that it was in the most market-oriented provinces where per-capita income grew fasted-particularly those provinces along the coast, Guangdong, Zhejiang, Fujian, and Jiangsu including Shanghai ${ }^{27}$ — but it does not follow that all the growth effects since reform can be attributed to market reform and trade liberalization. Our analysis shows that today, richer provinces seem to enjoy higher levels of integration and trade than poorer provinces (Figure 2, left). However, the same

\footnotetext{
${ }^{27}$ Indeed, our sample exhibits income divergence during the years 1986-93, in the sense that per-capita GDP in the four 'High' income provinces grew faster than GDP per capita in the four 'Low' income provinces.
} 
provinces that are rich today had relatively high levels of market integration and trade already about 270 years ago (Figure 2, right).

This is not to say that market reform has no growth effects, but in the $19^{\text {th }}$ and early $20^{\text {th }}$ century, China was strongly affected by war, political instability and foreign incursion. From the end of World War II until 1978, China was a socialist planning economy. Thus, it may well be that the $18^{\text {th }}$ century is the most recent time before the 1980s during which the market played the major role as China's allocation mechanism. Seen along these lines, the regional income dynamics in China since 1978 could just mean a return to the cross-province income differences that had existed in China a couple of centuries earlier. If this is the case, it would support the idea that regional economic disparities associated with market integration, trade, and geography are highly persistent. It would also suggest that the impact of reform is overstated.

The following section summarizes our results and contains additional discussion.

\section{Discussion}

This paper studies market integration and trade in China over almost three centuries. Our findings indicate that in the late $20^{\text {th }}$ century, although the law of one price does not hold, local and national prices essentially move one to one. Compared to historical levels of market integration, contemporary markets are more integrated. But we also find a significant degree of market integration for distances up to about 700 kilometers in China in the early $18^{\text {th }}$ century. Moreover, when we compare past differences in market integration and trade with today's differences in per-capita income, we find that the degree of market integration in the 1720 s is a very good predictor of per capita income in 
the 1990s. This paper does not analyze non-agricultural commodities directly, but considering the extent of structural change that has taken place over 270 years, it is quite stunning to see how well agricultural market integration in the past alone can predict today's income per capita.

In provinces where there is more trade and better market integration, we observe higher per-capita income. This appears to be the case both contemporaneously and over time. These systematic differences in trade and income however do not necessarily mean that trade causes growth — an equally plausible explanation is that trade and income are jointly determined. If the landlocked province of Guizhou were to trade in all goods and services to the same extent as Guangdong province, would Guizhou attain the per-capita income of Guangdong? The answer may be affirmative, but given the persistence of provincial differences over the centuries in the case of China, it is a scenario that seems unlikely. 


\section{References}

Acemoglu, Daron, Simon Johnson, and James Robinson (2002), "The Rise of Europe: Atlantic Trade, Institutional Change and Economic Growth”, NBER Working Paper \# 9378, NBER, Cambridge, MA.

Acemoglu, Daron, Simon Johnson, and James Robinson (2001), "The Colonial Origins of Comparative Development”, American Economic Review 91: 1369-1401.

Banerjee, Abhijit, and Laksmi Iyer (2003), "History, Institutions and Economic Performance: The Legacy of Colonial Land Tenure Systems in India”, BREAD working paper, Washington, D.C.

Chuan, Han-sheng and Richard A. Kraus (1975), Mid-Ch'ing Rice Markets and Trade: An Essay in Price History, Cambridge: Harvard University Press.

Clark, Gregory (2002), "Markets and Economic Growth, The Grain Market of Medieval England", working paper, University of California-Davis.

Coe, David, and Elhanan Helpman (1995), “International R\&D Spillovers”, European Economic Review 39: 859-887.

Crucini, Mario (1999), “On International and National Dimensions of Risk-Sharing”, Review of Economics and Statistics 81: 73-84.

Dinopoulos, Elias, and Paul Segerstrom (2003), “A Theory of North-South Trade and Globalization", working paper, University of Florida.

Frankel, Jeffrey, and David Romer (1999), “Does Trade Cause Growth?”, American Economic Review 89: 379-399.

Gong, Gaofa and Zhang Peiyuan. 1983. "Yingyong shiliao fenglian jizai yanjiu Beijing diqu xiangshui liang dui dong xiaomain shoucheng de yingxiang" (A Study of the Impact of Precipitation on the Beijing Harvest of Winter Wheat from the Historical Harvest Precipitation Records 1736-1978). In Qixiang xuebao 41.4.

Hummels, David (1999), “Time as a Trade Barrier”, working paper, Purdue University.

Irwin, Doug (2003), Comment on “Commodity Market Integration, 1500-2000” by R. Findlay and K. O'Rourke, in Globalization in Historical Perspective, eds. A. Taylor, M. Bordo, J. Williamson. Chicago: University of Chicago Press, pp. 62-64.

Keller, Wolfgang (1998), “Are International R\&D Spillovers Trade-related? Analyzing Spillovers Among Randomly Matched Trade Partners", European Economic Review 42: 1469-1481. 
Keller, Wolfgang, and Carol H. Shiue (2003), “The Origins of Spatial Interaction”, NBER Working Paper \#10069, NBER, Cambridge, MA.

O’Rourke, Kevin H. and Jeffrey G. Williamson. (2004), "From Malthus to Ohlin: Trade, Industrialization and Distribution Since 1500", working paper, Trinity College Dublin and Harvard University.

Perkins, Dwight. (1969), Agricultural Development in China 1368-1968. Chicago: Aldine Publishing Company.

Persson, Karl Gunnar (1999), Grain Markets in Europe, 1500-1900, Integration and Deregulation. Cambridge: Cambridge University Press

Playfair, George Macdonald Home (1965), Cities and Towns of China: A Geographical Dictionary, Taibei, Taiwan: Literature House, Ltd.

Pomeranz, Kenneth. (2000), The Great Divergence. Princeton: Princeton University Press.

Shiue, Carol H. (2002), "Transport Costs and the Geography of Arbitrage in $18^{\text {th }}$ Century China", American Economic Review 92 (5): 1406-1419.

Shiue, Carol H., and Wolfgang Keller (2003), "Markets in China and Europe on the Eve of the Industrial Revolution", working paper, University of Texas.

State Meteorological Society (1981), Zhongguo jin wubai nien hanlao fenbu tuji [Collected maps of droughts and floods in China in the past five hundred years]. Beijing: Ditu chuban she.

Wang, Daorui (1987). “Qing dai liang jia zouzhe zhidu de queli qi zuoyong.” (The reliability and function of the Qing grain price reporting system). Lishi dang'an, 4.

Wang, Yeh-chien (1973). Land Taxation in Imperial China, 1750-1911. Cambridge, MA: Harvard University Press.

Wang, Yeh-chien, (1989). "Food Supply and Grain Prices in the Yangzte Delta in the Eighteenth Century." Reprinted from The Second Conference on Modern Chinese Economic History, January 5-7, 1989. The Institute of Economics, Academia Sinica, Taipei, Taiwan.

Wilkinson, Endymion. (1969) "The Nature of Chinese Grain Price Quotations 16001900”, Transactions of the International Conference of Orientalists in Japan, no. 14: 5465.

Xu, Bin, and Jianmao Wang (2001), "Capital Goods Trade and R\&D Spillovers in the OECD”, Canadian Journal of Economics 32: 1258-1274. 
Young, Alwyn (2000), “The Razor's Edge: Distortions and Incremental Reform in the People's Republic of China”, Quarterly Journal of Economics 115: 1091-1135. 
Period 1723 to 1735

(1)

(2)

(3)

(4)

(5)

(6)

(7)

(8)

(9)

\begin{tabular}{|c|c|c|c|}
\hline $\begin{array}{l}\text { Local } \\
\text { Price }\end{array}$ & $\begin{array}{l}\text { Aggregate } \\
\text { Price }\end{array}$ & $\begin{array}{l}\text { Harvest } \\
\text { Quality }\end{array}$ & Weather \\
\hline 1.164 & 1.228 & 0.767 & 0.769 \\
\hline 0.092 & 0.129 & 0.153 & 0.725 \\
\hline 1.373 & 1.219 & 0.829 & 1.000 \\
\hline 0.250 & 0.125 & 0.132 & 0.707 \\
\hline 1.217 & 1.226 & 0.840 & 0.692 \\
\hline 0.305 & 0.121 & 0.107 & 0.480 \\
\hline 1.157 & 1.224 & 0.827 & 0.636 \\
\hline 0.280 & 0.126 & 0.136 & 0.809 \\
\hline 0.999 & 1.223 & 0.925 & 0.231 \\
\hline 0.194 & 0.123 & 0.035 & 0.599 \\
\hline 1.152 & 1.229 & 0.794 & 0.462 \\
\hline 0.128 & 0.134 & 0.097 & 0.877 \\
\hline 1.115 & 1.230 & 0.819 & 0.538 \\
\hline 0.144 & 0.126 & 0.049 & 0.776 \\
\hline 1.409 & 1.193 & 0.790 & 0.308 \\
\hline 0.133 & 0.113 & 0.110 & 0.630 \\
\hline 1.157 & 1.240 & 0.858 & 0.231 \\
\hline 0.132 & 0.134 & 0.086 & 0.439 \\
\hline 1.023 & 1.236 & 0.733 & 0.364 \\
\hline 0.272 & 0.124 & 0.208 & 0.505 \\
\hline 1.405 & 1.221 & $\mathrm{n} / \mathrm{a}$ & 0.077 \\
\hline 0.159 & 0.124 & $\mathrm{n} / \mathrm{a}$ & 0.277 \\
\hline 1.513 & 1.198 & 0.875 & 0.692 \\
\hline 0.194 & 0.115 & 0.029 & 0.630 \\
\hline 1.223 & 1.222 & 0.824 & 0.500 \\
\hline 0.244 & 0.121 & 0.108 & 0.671 \\
\hline 112 & 156 & 58 & 152 \\
\hline
\end{tabular}

$\begin{array}{ccccc}\begin{array}{c}\text { Local } \\ \text { Price }\end{array} & \begin{array}{c}\text { Aggregate } \\ \text { Price }\end{array} & \begin{array}{c}\text { Harvest } \\ \text { Quality }\end{array} & \text { Weather } & \begin{array}{c}\text { Weather } \\ \text { Variab. }\end{array} \\ 49.688 & 52.777 & 0.000 & 8.813 & 0.763 \\ 11.218 & 12.033 & 0.132 & 2.454 & 0.187 \\ 56.113 & 52.300 & 0.000 & 11.701 & 0.874 \\ 12.723 & 11.852 & 0.034 & 2.766 & 0.140 \\ 64.720 & 51.253 & 0.000 & 13.776 & 0.909 \\ 18.066 & 11.290 & 0.052 & 3.034 & 0.193 \\ 56.198 & 52.176 & 0.000 & 10.620 & 0.894 \\ 15.613 & 11.807 & 0.088 & 2.281 & 0.198 \\ 46.058 & 52.717 & 0.000 & 8.714 & 0.971 \\ 9.828 & 11.994 & 0.073 & 1.311 & 0.191 \\ 48.841 & 52.817 & 0.000 & 11.833 & 0.771 \\ 8.970 & 12.201 & 0.036 & 2.183 & 0.269 \\ 52.274 & 52.456 & 0.000 & 11.661 & 0.660 \\ 11.163 & 11.991 & 0.035 & 1.735 & 0.140 \\ 51.484 & 52.564 & 0.000 & 9.574 & 0.786 \\ 12.524 & 11.827 & 0.044 & 2.943 & 0.177 \\ 50.601 & 52.570 & 0.000 & 12.849 & 0.754 \\ 11.631 & 11.927 & 0.020 & 1.901 & 0.158 \\ 52.209 & 52.483 & 0.000 & 7.196 & 1.133 \\ 12.878 & 11.805 & 0.025 & 1.469 & 0.169 \\ 57.258 & 52.300 & 0.000 & 7.523 & 0.905 \\ 12.498 & 11.848 & 0.031 & 1.929 & 0.137 \\ 45.871 & 52.869 & 0.000 & 12.480 & 0.635 \\ 10.970 & 11.963 & 0.052 & 1.245 & 0.086 \\ & & & & \\ 52.459 & 52.440 & 0.000 & 10.562 & 0.838 \\ 12.855 & 11.179 & 0.057 & 2.924 & 0.212 \\ 93 & 96 & 96 & 96 & 96\end{array}$

Relative Size of Provinces

$\begin{array}{lcc} & \text { Anhwei } & \text { Fujian } \\ 1723-35^{*} & 0.083 & 0.030 \\ 1986-93^{* *} & 0.106 & 0.036 \\ & & \end{array}$

$\begin{array}{cccc}\text { Guangdong } & \text { Guangxi } & \text { Guizhou } & \text { Hubei } \\ 0.073 & 0.019 & 0.006 & 0.128 \\ 0.086 & 0.066 & 0.041 & 0.093\end{array}$
Hunan 075 0.095

Jiangsu
0.153
0.112

Jiangxi
0.214
0.066

Sichuan
0.100
0.178

Yunnan Zhejiang

0.062

0.100

** Total grain acreage, averaged for 1980 and 1985 
Table 2

Geographic Distance Between Provincial Capitals*

\begin{tabular}{|c|c|c|c|c|c|c|c|c|c|c|c|c|}
\hline Province & Anhwei & Fujian & Guangdong & Guizhou & Guangxi & Hubei & Hunan & Jiangsu & Jiangxi & Sichuan & Yunnan & Zhejiang \\
\hline Anhwei & & 389 & 1006 & 1120 & 898 & 255 & 494 & 234 & 245 & 1345 & 1524 & 298 \\
\hline Fujian & & & 788 & 1112 & 781 & 504 & 508 & 564 & 238 & 1454 & 1505 & 419 \\
\hline Guangdong & & & & 603 & 255 & 882 & 583 & 1239 & 766 & 1078 & 882 & 1183 \\
\hline Guizhou & & & & & 391 & 889 & 639 & 1333 & 956 & 478 & 405 & 1392 \\
\hline Guangxi & & & & & & 723 & 417 & 1130 & 683 & 847 & 741 & 1126 \\
\hline Hubei & & & & & & & 307 & 446 & 269 & 1089 & 1289 & 553 \\
\hline Hunan & & & & & & & & 720 & 319 & 947 & 1044 & 753 \\
\hline Jiangsu & & & & & & & & & 474 & 1514 & 1735 & 249 \\
\hline Jiangxi & & & & & & & & & & 1252 & 1359 & 445 \\
\hline Sichuan & & & & & & & & & & & 498 & 1641 \\
\hline Yunnan & & & & & & & & & & & & 1797 \\
\hline \multicolumn{13}{|l|}{ Zhejiang } \\
\hline Average & 710 & 751 & 842 & 847 & 727 & 655 & 612 & 876 & 637 & 1104 & 1162 & 896 \\
\hline Median & 494 & 564 & 882 & 889 & 741 & 553 & 583 & 720 & 474 & 1089 & 1289 & 753 \\
\hline
\end{tabular}

* Great circle distance in kilometers; source for historical locations of provincial capitals: Playfair (1965). 
Table 3: Market integration and trade in the years 1986 to 1993

Dependent variable: log local price

(1)

(2)

(3)

(4)

(5)

(6)

(7)'

$\begin{array}{lllllll}\text { Aggregate } & 0.966^{\star *} & 0.954^{* *} & 0.972^{\star *} & 0.971^{\star *} & 0.973^{\star *} & 0.971^{\star *} \\ \text { Price } & (0.047) & (0.047) & (0.048) & (0.050) & (0.041) & (0.044)\end{array}$

Aggregate

Price 1986-89

Aggregate

$0.899^{\star \star}$

Price 1990-93

Weather

0.063

$0.076^{*}$

0.073

0.016

0.005

$(0.043)$

$(0.044)$

(0.047)

(0.049)

(0.052)

\section{Weather}

Variability

$0.094^{*}$

0.091

$-0.004$

$-0.013$

(0.052)

(0.053) (0.043)

(0.042)

Harvest

$\begin{array}{ll}-0.060 & -0.193\end{array}$

quality

$(0.321)$

(0.233)

Province FEs

No

No

No

No

Yes

Yes

Yes

Rbar sq

0.756

0.758

0.765

0.762

0.888

0.889

0.889

All regressions include a constant (not reported)

Heteroskedasticity-consistent (Huber-White) standard errors in parentheses

$\left.{ }^{* *}{ }^{*}\right)$ means larger than 0 at a $5 \%(10 \%)$ significance level

Aggregate price defined in eq. (2); weather is log average annual rainfall

Weather variability is log coefficient of variation of monthly rainfall

Harvest quality variable described in section 3

' Regression also allows for period-specific intercepts (not reported) 
Table 4: Market integration in the years 1723 to 1735

Dependent variable: log local price

(1)

(2)

(3)

(4)

(5)

$\begin{array}{lccccc}\text { Aggregate } & 0.530^{* *} & 0.488^{* *} & 0.089 & 0.474^{* *} & 0.412 \\ \text { Price } & (0.170) & (0.166) & (0.321) & (0.141) & (0.263) \\ \text { Weather } & & 0.058^{* *} & 0.062 & 0.041 & 0.009 \\ & & (0.028) & (0.045) & (0.026) & (0.039) \\ \text { Harvest } & & & & & \\ \text { quality } & & & \begin{array}{c}-0.686^{* *} \\ (0.285)\end{array} & & \begin{array}{c}0.865^{\star *} \\ \text { Province FEs }\end{array} \\ \text { No } & \text { No } & \text { No } & \text { Yes } & \text { Yes } \\ \text { N } & 112 & 110 & 56 & 110 & 56 \\ \text { Rbar sq } & 0.056 & 0.093 & 0.147 & 0.394 & 0.488\end{array}$

All regressions include a constant (not reported)

Heteroskedasticity-consistent (Huber-White) standard errors in parentheses

${ }^{* *}\left({ }^{*}\right)$ means larger than 0 at a $5 \%(10 \%)$ significance level

Aggregate price defined in eq. (2); weather is |dryness-3|, see section 3

Harvest quality variable described in section 3 
Table 5: The geographic scope of market integration over time

Dependent variable: log local price

1723 to 1735

1986 to 1993

$\begin{array}{llll}(1 a) & (2 a) & (3 a) & (4 a)\end{array}$

$\begin{array}{lcccc}\text { Aggregate } & 0.578^{* *} & 0.554^{\star *} & 0.381 & 0.559^{\star *} \\ \text { Price-Near } & (0.170) & (0.161) & (0.252) & (0.205) \\ & & & & \\ \text { Aggregate } & 0.028 & -0.021 & -0.123 & 0.038 \\ \text { Price-Far } & (0.088) & (0.083) & (0.153) & (0.137) \\ & & & & \\ \text { Weather } & & 0.053^{\star *} & 0.065 & 0 \\ & & (0.025) & (0.042) & (0.040)\end{array}$

Weather

variability

Harvest

$-0.571^{* *}-0.766^{* *}$

quality

$(0.277) \quad(0.230)$

Province FEs

No No No Yes

$\mathbf{N}$

110

108

$54 \quad 54$

Rbar sq

0.126

0.150

0.169

0.533

(1b)

(2b)

(3b)

(4b)

$\begin{array}{llll}0.618^{\star *} & 0.608^{\star *} & 0.607^{* *} & 0.447^{\star *}\end{array}$

$\begin{array}{llll}(0.151) & (0.147) \quad(0.146) & (0.169)\end{array}$

$0.344^{* *} \quad 0.352^{* *} \quad 0.352^{* *} \quad 0.516^{* *}$

$\begin{array}{llll}(0.144) \quad(0.145) & (0.145) \quad(0.155)\end{array}$

$0.086^{* *} \quad 0.086^{*} \quad 0.007$

$\begin{array}{lll}(0.042) & (0.045) \quad(0.053)\end{array}$

$\begin{array}{lll}0.068 & 0.067 & -0.011\end{array}$

$(0.053) \quad(0.057) \quad(0.044)$

$-0.018 \quad-0.158$

$(0.327) \quad(0.245)$

All regressions include a constant (not reported)

Heteroskedasticity-consistent (Huber-White) standard errors in parentheses

**(*) means larger than 0 at a $5 \%(10 \%)$ significance level

Definitions of variables are as in Tables 3 and 4, respectively 


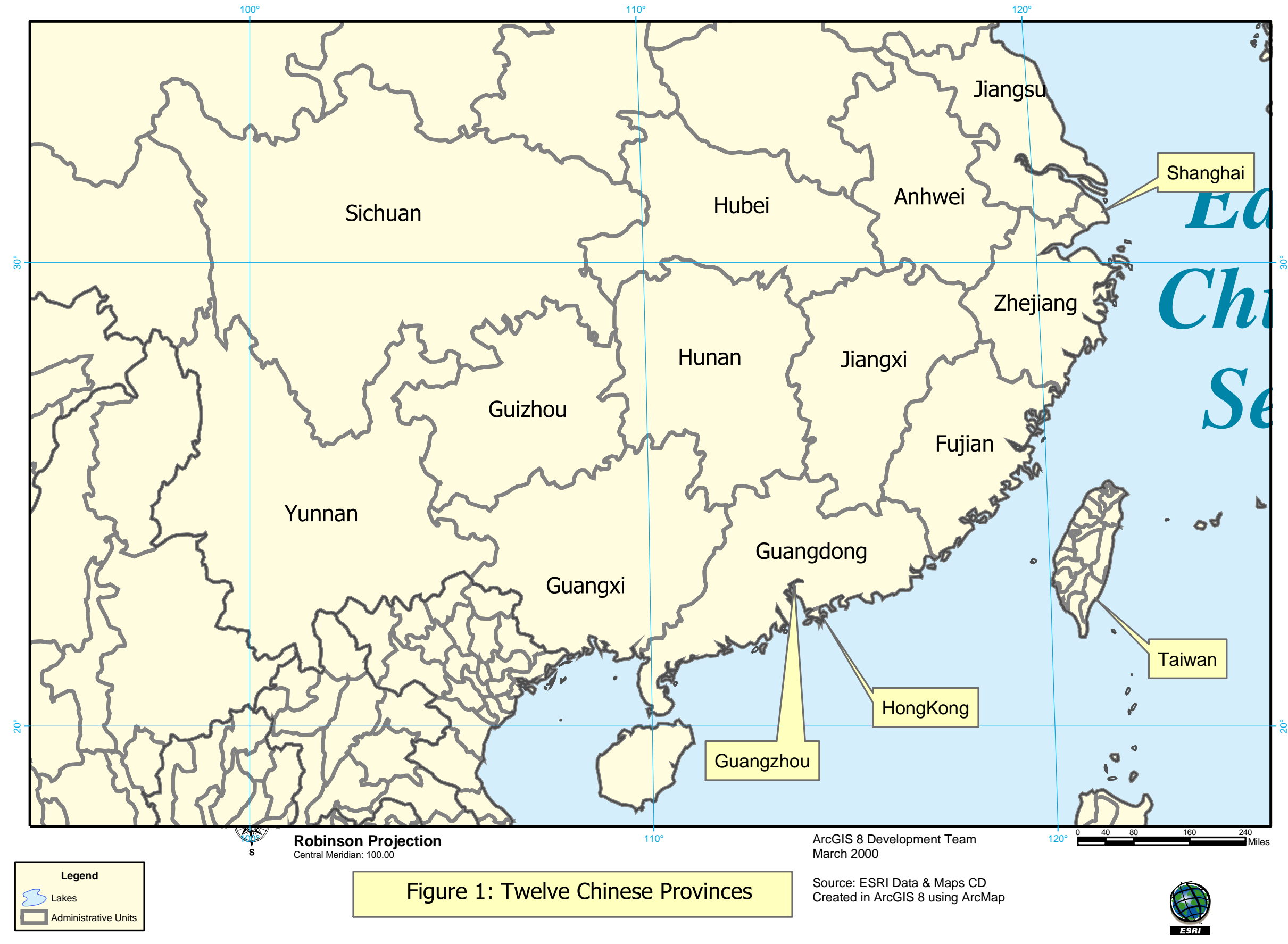


Figure 2: Market Integration, Trade, and Income across China: Now and Then

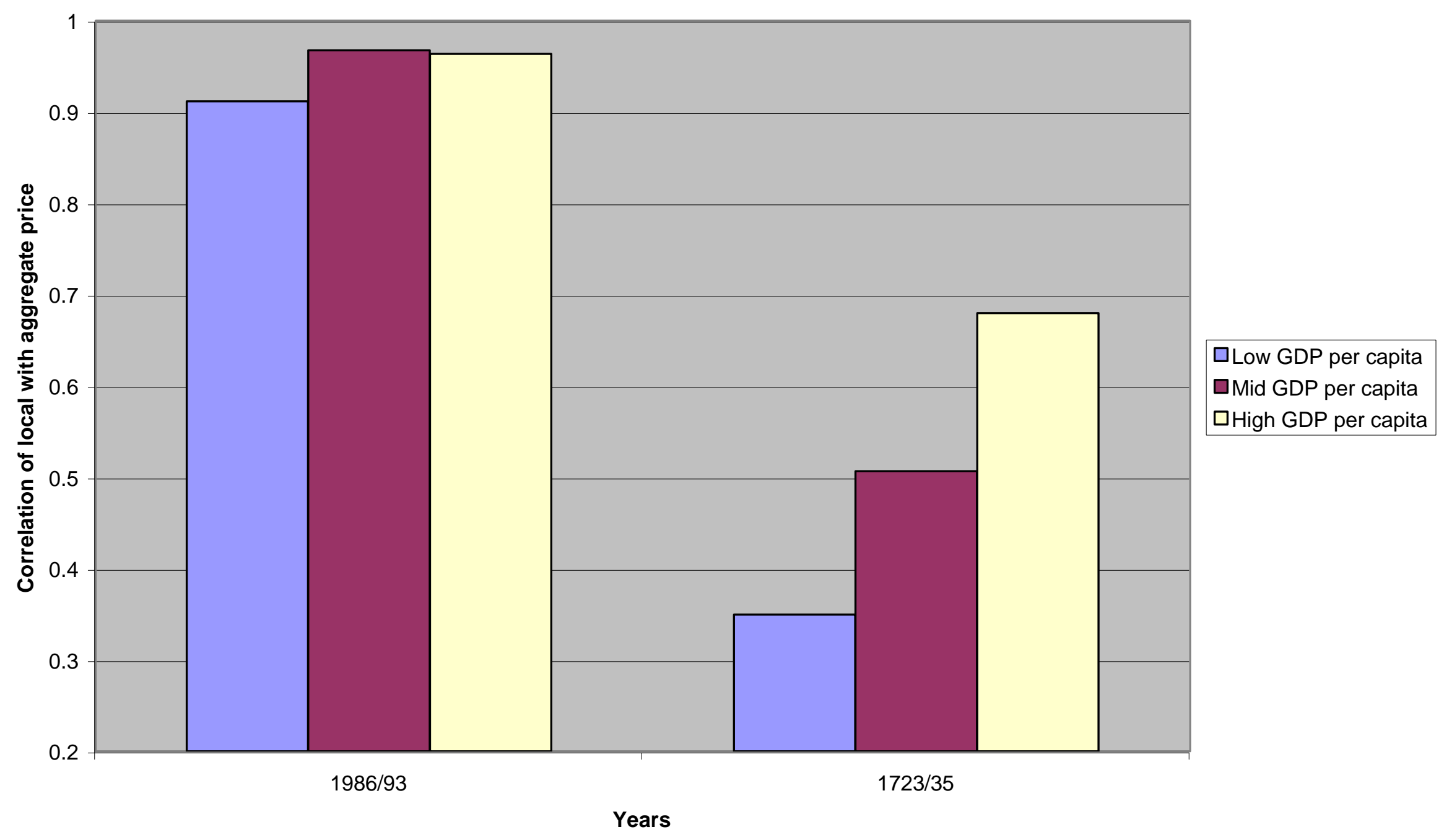

